\title{
Kwanyama Language
}

National Cancer Institute

\section{Source}

National Cancer Institute. Kwanyama Language. NCI Thesaurus. Code C153990.

A Niger-Congo language that is the national language of Angola and Namibia. 